\title{
JOURNAL.RU
}

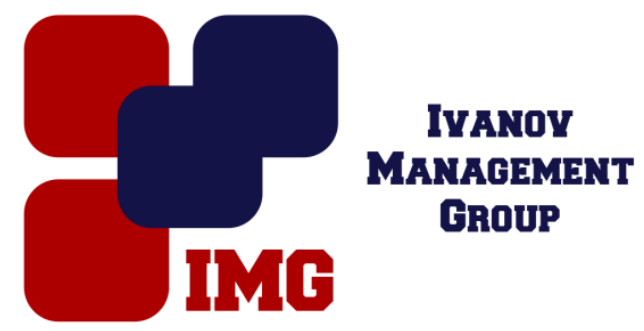

Токова М.P. Северо-Кавказская государственная гуманитарно-технологическая академия, Юридический институт Черкесск, Россия

doi: $10.18411 / 1 \mathrm{j}-31-05-2017-53$

idsp 000001:1j-31-05-2017-53

\section{Борьба с рецидивом преступлений}

Грозное выражение «рецидив», наводящий панику на законопослушных граждан и благоговейную нервную дрожь на представителей преступного мира происходит от латинского слова «recidivus», и означает «возврат, повторное проявление». Мы часто слышим это слово в сводках криминальных новостей. Впрочем, сфера применения этого понятия намного шире: им обозначают рекуррентную волну кризиса в экономике (например, рецидив существенно незапланированного подъема цен), или периодическое возникновение заболевания после очевидного излечения в медицине.

По общему мнению, под рецидивом преступлений понимается вариация повторности. В соответствии с ч.1 ст.18 УК РФ «рецидивом преступлений признается совершение умышленного преступления лицом, имеющим судимость за ранее совершенное умышленное преступление».

Ядром этого термина служит присутствие хотя бы одной судимости за ранее совершенное умышленное общественно-опасное деяние у лица, привлекаемого к уголовной ответственности за повторно совершенное им преступное деяние. Это условие позволяет отграничить рецидив от совокупности преступлений. Снятые и погашенные судимости, а также судимости за преступления, совершенные лицом в возрасте до 18 лет, не учитываются при признании рецидива преступлений. Однако неснятые и непогашенные судимости в соответствии со ст. 16 УК образуют признак неоднократности (он как вид множественности преступлений утратил силу). Указание на умышленную форму вины обоих (или более) преступлений 
конкретизирует понятие рецидива и исключает возможность признания лица рецидивистом в случае совершения им неосторожного преступления или наличия судимости за неосторожное преступление.

Уголовный Кодекс РФ выделяет рецидив, опасный рецидив и особо опасный рецидив преступлений. Одновременно, в криминологии принято различать «легальный» (уголовно-правовой), «фактический» (криминологический), «пенитенциарный» и «постпенитенциарный» рецидив. Считаем, приведенное разграничение, имеет определенную роль для кондиционного исследования характеристик, причин и условий определенного вида рецидива, формированию мер по предотвращению рецидивной преступности. На самом деле, уголовно-правовой и криминологический подход к определению рецидива преступлений значительно различаются вследствие неучета уголовным законом числа судимостей (за преступления небольшой тяжести, совершенные до 18 лет; с условным осуждением/отсрочкой исполнения приговора). Соответственно показатели «фактического» рецидива значительно выше показателей «легального».

Рецидив не усиливает общественной опасности содеянного. К примеру, если особо опасный рецидивист (прежде никого не убивавший) совершит убийство супруги из-за ревности, то от этого общественная опасность такого убийства не увеличивается, а УК РФ это убийство определяет как убийство при отягчающих обстоятельствах лишь потому, что его совершил особо опасный рецидивист. И, следовательно, он в противовес, скажем, от алкоголика, аналогично убившего жену, может быть осужден вместо лишения свободы от 3 до 10 лет к лишению свободы от 8 до 15 лет со ссылкой или без ссылки или к смертной казни.

Возникает вопрос: За что такое несправедливое отношение? Или, почему за нанесение тяжких телесных повреждений несудимый и даже судимый гражданин может быть, как минимум наказан только 3 месяцами лишения свободы, а особо опасный рецидивист как минимум - 5 годами лишения свободы, т. е. в 20 раз строже! Та же самая несправедливость, допускается и при осуждении по другим статьям Особенной части уголовного законодательства, в которых особо опасный рецидив отягчает ответственность. Собственно из этого следует, что так называемая общественная опасность личности преступника в более решающей степени устанавливает размер уголовной ответственности по сравнению с общественной опасностью самого деяния. 
Как только не старались обосновать высокую ответственность за рецидив. Но все это не является весомым, поскольку должно функционировать правило: «за одно деяние - одно наказание».

Численность осужденных в России снижается гораздо медленнее, чем в соседних странах. Одной из причин является фактическая ликвидация института условно-досрочного освобождения. Из-за общего снижения преступности в стране число «новых» осужденных уменьшается, а лица, осужденные в предыдущие годы, не могут освободиться досрочно. Если десять лет назад условно-досрочно освобождался каждый второй осужденный, то сейчас каждый пятый.

Показатель рецидивной преступности среди ранее осужденных лиц продолжает возрастать. Фактором является, преимущественно, низкий уровень эффективности работы уголовно-исполнительной системы. Воздействие недоработки судебной системы несколько меньше, но оно также обнаруживается. Осужденным все еще очень трудно добиться обжалования действий исправительных учреждений в судебных инстанциях.

Заключенные стремящиеся вести законопослушный образ жизни, часто получают неоднократный отказ в условно-досрочном освобождении, что подрывает их веру в справедливость судебной системы и провоцирует возврат к преступному образу жизни. Наблюдается значительная корреляционная связь между сокращением возможностей досрочного освобождения из мест лишения свободы и уровнем рецидивной преступности.

С нашей точки зрения, обостренная общественная угроза рецидивной преступности, вызвана тем, что совершение преступления лицом, прежде привлекавшегося к ответственности за уголовно наказуемые деяния (второй и более раз), доказывает его настойчивое желание вести противозаконную деятельность и дальше, пренебрежение моральных, этических, духовных и нравственных норм, неготовность вести общественно-социальный допустимый образ жизни. Указанные лица интенсивно затягивают в преступную деятельность иных граждан, в особенности из числа подрастающего поколения, формируя преступные, противозаконные группы, в том числе и организованные.

Проблема рецидива у ранее осужденных лиц становится все более актуальным и значимым в ситуациях универсальной редукции преступности и предпринимаемых государством мер по обеспечению и гарантии правопорядка.

Наряду с этим, вопросам модернизации тюремной системы на федеральном уровне уделяется сравнительно большое внимание. В 2010 г. была 
принята «Концепция развития уголовно-исполнительной системы РФ до 2020 г.», одной из главных задач которой была «сокращение рецидива преступлений, совершенных лицами, отбывшими наказание в виде лишения свободы, за счет повышения эффективности социальной и психологической работы в местах лишения свободы, проведение в местах лишения свободы мероприятий в целях адаптации в обществе освободившихся осужденных, в том числе с участием гражданского общества».

Вне зависимости от колоссальных финансовых вливаний государства и роста финансирования, уровень рецидивной преступности продолжает увеличиваться. Это позволяет сделать вывод о том, что проблема заключается не в недостатке финансового обеспечения, а в том, что в настоящем виде уголовноисполнительная система бесповоротно перестала осуществлять свою главную функцию и задачу исправления преступников и обеспечения их организации к предстоящей естественной жизни в обществе.

Эффективные механизмы контроля за деятельностью тюремной системы также не появились. Обжаловать действия тюремного ведомства обычному осужденному крайне затруднительно - система закрыта от общественного контроля, прокуратура по надзору за исправительными учреждениями зачастую не реагирует на обращения заключенных.

В ходе нашего анализа было обнаружено присутствие непосредственной обусловленности между уровнем рецидивной преступности и досрочным освобождением осужденных лиц из мест лишения свободы. Наличие подобной обусловленности толкуется тем, что лица, которым неоднократно было отказано в таком акте гуманизма (а зачастую, и справедливости) как условно-досрочное освобождение, более подвержены к повторному, рецидивному совершению преступлений. Для многих заключенных, в особенности уже отбывших длительный срок наказания, сама процедура рассмотрения их ходатайства об условно-досрочном освобождении становится тяжелым моральным испытанием и внутренним экзаменом - он занимает порядком не малое количество времени, которое осужденный проводит в состоянии и обстановке неопределенности и неясности касательно своего будущего.

Ученые и психологи считают, что вопрос рецидивной преступности многообразен и своим социо- и индивидуально-психологическим аспектом, с мнением которых мы согласимся. Преступники-рецидивисты, в большинстве случаев, неординарные личности, с прочным, выносливым характером, обладающие управленческим потенциалом, притягивающие своими качествами 
и чертами к себе других людей. Впрочем, психологическая обстановка, складывающаяся около рецидивиста, специфична тем, что, личность его, помимо всего прочего, сеет вокруг себя страх, который буквально подавляет и полностью лишает человеческого достоинства людей, слабых характером. Разумеется, мир рецидива безжалостен, духовные ценности в нем перевернуты, цена жизни мизерна. Следовательно, преступления, в которых участвует или которыми руководит рецидивист в основном жестоки, отличаются бесстрашием замысла и исполнения, осторожностью и предусмотрительностью. Затем, как правило, в деятельности приходит затишье или попадание в сферу правоохранительных органов за небольшие преступления. А здесь уже ждет молодое поколение, которые становятся в дальнейшем сообщникам и партнерами.

Мир рецидивистов для специалистов всех областей (юристов, психологов) пожалуй, самый сложный для понимания. Но, по нашеу мнению, понять и воспринять его нереально, так как для этого должна существовать абсолютно другая психология. Но знание закономерностей, по которым он живет - знать надо.

1. Уголовный кодекс Российской Федерации от 13.06.1996 № 63-Ф3 (ред. от 03.04.2017) // Собрание законодательства РФ. 17.06.1996. № 25.

2. Распоряжение Правительства РФ от 14.10.2010г. N 1772-p «Об утверждении Концепции развития уголовно-исполнительной системы Российской Федерации до 2020 года» (с изменениями на 23.09. 2015 г.).

3. Гамзатов, М. Латинско-русский словарь юридических терминов и выражений для специалистов и переводчиков английского языка / М. Гамзатов. - М.: СПб: СанктПетербургский Университет, 2016г. 